\title{
KONSEP BERPIKIR (AL-FIKR) DALAM ALQURAN \\ DAN IMPLIKASINYA TERHADAP PEMBELAJARAN PAI \\ DI SEKOLAH (Studi Tematik tentang Ayat-ayat yang Mengandung Term al-Fikr)
}

\author{
Taufik Hidayat*, \\ Aam Abdusalam, Fahrudin \\ Program Studi Ilmu Pendidikan Agama Islam \\ Fakultas Pendidikan Ilmu Pengetahuan Sosial, Universitas Pendidikan Indonesia \\ *E-mail : taufik.hidayat65@student.upi.edu
}

\begin{abstract}
ABSTRAK
Pendidikan harus menghasilkan siswa yang cerdas dalam ilmu pengetahuan dan mempunyai karakter yang baik. Berpikir merupakan aktivitas manusia yang sangat mendasar untuk pembinaan dan pengembangan diri. Para ilmuan, ahli pendidikan bahkan Alquran telah mengemukakan pentingnya memberdayakan kemampuan berpikir khususnya dalam pendidikan. Akan tetapi kenyataan tersebut kurang disadari sebagian besar umat muslim sehingga masih tertinggal dibandingkan umat lain. Padahal berpikir adalah sumber kekuatan untuk meraih peradaban. Penelitian ini bertujuan untuk menemukan konsep berpikir dalam Alquran kemudian dicari implikasinya terhadap pembelajaran PAI di sekolah. Penelitian ini menggunakan pendekatan kualitatif dengan mengoperasikan metode tafsir maudu' ', dengan menelusuri dan menganalisis seluruh term الفكر (al-fikr) dalam Alquran. Data primer penelitian ini adalah ayat-ayat dengan term الفكر (al-fikr), sedangkan data sekunder adalah tafsir, buku, jurnal dan literatur lain yang menunjang. Penelitian ini menemukan: tujuan berpikir dalam Alquran yaitu, 1) mendapatkan kebenaran, 2) mengamalkan syariat Islām, 3) lebih dekat dengan Allāh Swt, dan terakhir 4) berakhlak baik. Kedudukan berpikir dalam Alquran yaitu sangat dimuliakan, mendapat rahmat, dan tehindar dari azab Allāh. Selain itu adapula cara berpikir menurut Alquran yaitu; 1) berpikir dengan hati yang bersih, 2) berpikir dengan logika atau akal yang benar disertai bimbingan wahyu, 3) berpikir luas dengan cara yang sederhana agar mudah dipahami, 4) terbuka dengan pemikiran orang lain, dan terakhir, 5) berpikir dari proses hingga dampak yang dihasilkan. Adapun manfaat berpikir yang dimaksud dalam Alquran yaitu, 1) mengetahui hikmah dari syariat Islām, 2) mengetahui hikmah dan tujuan ciptaan Allāh Swt, 3) termotivasi melakukan kebaikan, 4) diangkat derajatnya, 5) terhindar dari hawa nafsu, dan 6) mendapat ilmu pengetahuan. Berdasarkan penelitian ini, konsep berpikir dalam Alquran memiliki ilmplikasi terhadap rancangan, perencanaan, proses, dan evaluasi pembelajaran PAI di sekolah.
\end{abstract}

Kata Kunci: Berpikir, Alquran, PAI. 


\section{PENDAHULUAN}

Dalam Alquran banyak ayat memerintahkan untuk berpikir, bahkan sering menyindir dengan keras mengapa manusia jarang sekali berpikir sehingga sulit mendapat hidayah kebenaran. Alquran sebagai mukjizat Nabi Muhammad Saw terletak pada kandungan intelektual di dalamnya, berbeda dengan mukjizat para nabi terdahulu yang kebanyakan bersentuhan dengan hal-hal magis. Alquran memerintahkan kita untuk berpikir merenungi kehebatan ciptaan Allāh Swt di alam semesta, kejadian umat terdahulu, perumpamaan, serta masih banyak lagi yang kesemuanya menggunakan pendekatan untuk berpikir dan merenung dengan baik.

Ajaran Islām dan juga para ahli memuliakan sikap berpikir. Sungguh mengherankan, dalam ajaran Islām diperintahkan untuk selalu berpikir, menelaah, meneliti, dan mengambil hikmah dari alam semesta, namun kebanyakan umat muslim sekarang justru tidak memahami hal ini. Banyak orang muslim yang tidak paham bahwa berpikir sangat ditekankan dalam ajaran Islām. Akibatnya umat muslim sekarang mengalami kemunduran dibanding umatumat lainnya. Padahal berpikir adalah sumber kekuatan bagi manusia untuk mencapai kemajuan dalam peradaban dan mendekatkan diri pada Allāh Swt.

Dalam pelajaran PAI di sekolah kegiatan berpikir sangatlah diperlukan. Ajaran Islām hanya bisa dijalankan oleh orang-orang yang berpikir, maka dari itu guru PAI harus mendidik dengan melakukan pendekatan berpikir. Dengan berpikir maka siswa akan memahami materi pembelajaran dan lebih semangat untuk lebih menggali ilmu dari materi pembelajaran. Jika siswa telah memahami apa maksud, tujuan, hikmah dan manfaat dari materi pembelajaran PAI, maka dengan penuh kesadaran sendiri ia akan berusaha untuk terus mengamalkannya dan menerapkannya dalam kehidupan seharihari.

\section{METODE}

Penelitian ini memakai pendekatan kualitatif dengan teknik deskriptif menggunakan metode penafsiran maudu' $\bar{\imath}$ kemudian dicari implikasinya yang bisa diterapkan terhadap pembelajaran PAI di sekolah. Musthafa Muslim (2007, hlm. 115) mengemukakan bahwa tafsir maudu' ialah tafsir yang membahas tentang masalah-masalah Alquran al-Karīm yang memiliki kesatuan atau tujuan dengan cara menghimpun ayat-ayatnya yang bisa juga disebut metode tauhidi (kesatuan) untuk kemudian melakukan penalaran (analisis) terhadap isi kandungannya menurut caracara tertentu dan berdasarkan syarat-syarat tertentu untuk menjelaskan maknamaknanya dan mengeluarkan unsurunsurnya, serta menghubung-hubungkan antara yang satu dan lainnya dengan korelasi yang bersifat konfrehensif. Penelitian ini menggunakan teknik pengumpulan data studi pustaka. Menurut Sukmadinata (2012, hlm. 216) studi pustaka berusaha mengumpulkan data dengan cara menggunakan buku-buku, literatur, bahan pustaka yang menunjang.

\section{HASIL DAN PEMBAHASAN}

\section{Komposisi Ayat-ayat tentang Berpikir dalam Alquran}

Komposisi yang dimaksud di sini yaitu memaparkan ayat-ayat term الفكر (Al$F i k r)$ berdasarkan rumusan masalah yang telah dikemukakan sebelumnya. Adapun jumlah ayat-ayat tersebut sebanyak 18 ayat. Berikut susunan berdasarkan tertib turunnya ayat yang berpedoman pada buku Ulumul Qur'ān karya Izzan (2013, hlm. 88): Al-Mudaṡsirir ayat 18, Al-Arāf ayat 176 dan 184, Yūnus ayat 24, Al-An'ām ayat 50 , Saba' ayat $46, \mathrm{Az}-\mathrm{Zumar}$ ayat 42 , Al-Jāsiyah ayat 13, An-Naḥl ayat 11, 44, 
dan 69, Ar-Rūm ayat 8 dan 21, Ar-Ra'd ayat 3, Al-Baqarah ayat 219 dan 266, ĀlImrān ayat 191, dan Al-Ḥāsyr ayat 21. Peneliti menemukan hubungan yang erat tentang tujuan berpikir, menfaat berpikir, cara berpikir, dan kedudukan berpikir, sebagai berikut:



\section{Tujuan Berpikir (Al-Fikr) dalam Alquran}

Dari analisis terhadap ayat-ayat dengan term Al-Fikr (الفكر), peneliti menemukan tujuan berpikir dalam Alquran sebagai berikut:

a. Mendapatkan Kebenaran;

Berdasarkan asbab nuzul surah AlMudaṡsir ayat 18 , ayat ini mengecam sikap Al-Walid Al-Mugirah yang telah berpikir jernih dan menemukan kebenaran namun malah berpaling karena dorongan nafsu dan duniawi (Hamka, 1985, hlm. 209). Maka dari itu tujuan berpikir yaitu agar menemukan kebenaran sebagaimana yang sempat dirasakan Al-Walid walaupun pada akhirnya ia malah berpaling, padahal sempat berpikir dengan baik dan mendapatkan kebenaran. Surah Al-Arāf ayat 176 juga terdapat kaitannya dengan Al-Mudaśsiir ayat 18 karena mengecam orang yang menuruti hawa nafsunya, padahal seandainya ia tidak mengikuti hawa nafsu kemudian mengikuti kebenaran niscaya Allāh akan meninggikan derajatnya (Al-Jazairi, 2010, hlm. 200). Begitulah yang terjadi terhadap Al-Walid. Allāh memerintahkan untuk menceritakan kisah-kisah tersebut agar dipikirkan sehingga mendapatkan kebenaran.

Dalam surah Al-An'ām ayat 50, ayat ini memerintahkan manusia berpikir agar mendapatkan kebenaran dan terhindar dari kesesatan/takhayul. Ayat ini berusaha meluruskan pandangan sesat kaum Quraisy tentang kenabian, maka mereka diperintahkan untuk berpikir kembali. Bahkan Allāh menyindir bahwa tidak sama orang yang berpikir dengan yang tidak, ibarat orang yang buta dengan orang yang melihat (Quthb, 2004, hlm. 93). Dalam surah An-Nahl ayat 44 peneliti menemukan bahwa ayat ini merupakan penegasan kenabian supaya mereka memikirkannya sehingga dapat mengetahui kebenaran tentang apa yang dibawa rasul pada mereka yaitu wahyu dan syariat. Apa yang dibawa rasul adalah peringatan dan membawa kebaikan, maka hendaklah mereka memikirkannya (AlJazairi, 2010, hlm. 212).

b. Mengamalkan Syariat Islām;

Sebelum mengamalkan syariat Islām, manusia harus meyakini terlebih dahulu bahwa syariat Islām adalah benar begitupun dengan orang yang membawa risalahnya. Al-Qur'ān mengajak manusia memikirkan bahwa Nabi Muhammad Saw adalah benar bukanlah pendusta. Al-Arāf ayat 184 membantah tuduhan buruk kaum Quraisy terhadap Nabi Muhammad Saw (Shihab, 2008, hlm. 327). Surah Saba' ayat 46 mengajak mereka untuk memikirkan kembali siapa sebenarnya Nabi Muhammad Saw (Hamka, 1988, hlm. 190). 
Setelah memikirkan siapa yang membawa risalahnya, maka peneliti menemukan bahwa Al-Qur'ān mengajak manusia untuk memikirkan apa yang terdapat dalam risalah itu. Surah AlBaqarah ayat 219 merupakan ajakan AlQur'ān untuk memikirkan syariat Islām mengenai pelarangan khamr karena keburukannya yang lebih banyak dibandingkan dengan manfaatnya (Thabathaba'i, 2011, hlm. 350). Begitupun dengan syariat Islām yang melarang sikap riya dalam setiap amalan. Surah AlBaqarah ayat 266 menjelaskan perumpamaan mengenai prilaku riya agar manusia lebih bisa memahami dan menghayatinya (Al-Qarni, 2007, hlm. 213). Bahkan dalam Al-Hāsyr ayat 21 menegaskan bahwa Alquran yang mengandung syariat ini merupakan tanggung jawab yang besar yang diberikan pada manusia. Jika diberikan pada gunung niscaya gunung itu hancur akibat ketakutannya tidak bisa menjaga amanah ini. Sungguh disayangkan kebanyakan manusia malah mengabaikan tidak memikirkannya apalagi mengamalkannya (Ath-Thabari, 2009, hlm. 919).

\section{c. Lebih Dekat dengan Allāh}

Berpikir dengan baik dapat membuat seseorang mengenal Allāh Swt sehingga lebih dekat dengan-Nya sebagaimana surah Al-Mudaṡsir ayat 8 mengenai AlWalid Al-Mughirah yang sempat dekat dengan petunjuk Allāh, namun setelah itu ia malah memilih mengikuti hawa nafsunya (Hamka, 1985, hlm. 212). Adapun dalam surah Āl-Imrān ayat 191 menggambarkan dengan jelas bagaimana orang yang selalu memikirkan dan mengingat kekuasaan Allāh Swt akan selalu dekat dengan Allāh Swt (Al-Qarni, 2007, hlm. 346).

Begitupun temuan peneliti dalam surah Al-Jāsiyah ayat 13, An-Naḥl ayat 11 dan 69, Ar-Rūm ayat 8, dan Ar-Ra'd ayat 3 Allāh Swt mengajak manusia memikirkan bagaimana hebatnya alam semesta yang telah Allāh ciptakan dan tundukan. Semua keteraturan dan keberagaman yang ada di alam semesta tak mungkin tercipta dengan sendirinya. Hal ini membuktikan adanya zat sebagai pencipta dan pengaturnya yaitu Allāh Swt.

\section{d. Berakhlak Baik.}

Dari surah Al-Baqarah ayat 219 dan 266 peneliti menemukan bahwa Allāh memerintahkan manusia untuk berpikir mengenai hal-hal yang dapat menghalangi bahkan merusak manusia dari perbuatan baik, yaitu khamr dan riya. menurut Thabathaba'i (2011, hlm. 350) efek buruk dari khamr adalah menghalangi fungsi akal dari membedakan sesuatu yang baik dan buruk, orang yang terbiasa mengkonsumsinya akan sulit berakhlak baik.

Adapun bahaya dari riya dapat merusak dan menghapus amalan baik (AlQarni, 2007, hlm. 213). Manusia tidak akan mampu berakhlak baik jika dilandaskan riya. Amalan baik yang dilandasi karena Allāh maka akan bertambah rasa cintanya pada Allāh, sedangkan amalan berlandaskan nafsu dan duniawi maka akan bertambah cinta pula ia padanya dan melupakan Allāh. Sungguh bahaya jika amalan baik manusia disandarkan pada nafsu dan duniawi seperti harta, jabatan, dan syahwat, jika tak ada hal itu mungkin ia tidak akan melakukan kebaikan lagi. Inilah bahaya dari khamr dan riya, maka hendaklah manusia memikirkannya sehingga mengatahui bahayanya dan bisa berakhlak baik sesuai fitrahnya.

\section{Manfaat Berpikir (Al-Fikr) dalam Alquran}

Dari analisis terhadap ayat-ayat yang terdapat term Al-Fikr ( الفكر ) peneliti menemukan manfaat berpikir sebagai berikut:

a. Mengetahui Hikmah dari Syariat Islām;

Allāh Swt memberikan potensi akal dan memerintahkan berpikir pada setiap manusia agar dapat memahami hikmah 
dari syariat Islām. Namun manusia yang tidak menggunakan akal baiknya atau terhalang oleh hawa nafsu dan kecintaan dunia tidak akan mampu memahaminya sebagaimana kisah Al-Walid dalam surah Al-Mudaṡsir ayat 18 (Hamka, 1985, hlm. 211). Mengenai syariat yang melarang khamr, surah Al-Baqarah ayat 219 mengajak manusia memikirkan bahwa lebih banyak kerugian dan kerusakan akibat khamr dibandingkan manfaarnya (Thabathaba'i, 2011, hlm. 350). Begitupun dengan surah Al-Baqarah ayat 266 yang menjelaskan dengan perumpamaan yang sederhana mengenai bahaya amalan berdasarkan riya (Thabathaba'i (2011, hlm. 332). Maka dari itu dalam temuan peneliti, dengan berpikir yang baik manusia akan mengetahui hikmah dari syariat Islām yang sebenarnya membawa kebaikan pada dirinya.

b. Mengetahui Hikmah dan Tujuan Ciptaan Allāh;

Dalam analisis peneliti menemukan beberapa ayat yang menjelaskan hikmah dan fungsi dari ciptaan Allāh di alam semesta ini untuk menjadi bahan renungan dan berpikir bagi manusia. Misalnya surah Āl-Imrān ayat 191 menggambarkan bagaimana keadaan orang yang selalu berpikir dan mengingat Allāh Swt akan menyadari bahwa segala penciptaan Allāh Swt di alam semesta ini tidak sia-sia dan merupakan tanda-tanda kekuasaan-Nya (Hamka, 1993, hlm. 198). Surah Ar-Ra'd ayat 3 menyeru manusia bahwa bumi yang terbentang luas, buah-buahan yang beraneka ragam, gunung dan sungai semuanya adalah tanda-tanda kekuasaan Allāh Swt dan mempunyai fungsi dan perannya masing-masing (Katsir, 2006, hlm. 477). Bahkan dalam surah An-Nahl ayat 11 dan Al-Jāsiiyah ayat 13 menjelaskan bahwa alam semesta itu diciptakan serta ditundukan untuk keperluan manusia sebagai khalifah (AthThabari, 2009, hlm. 282). Bukan hanya penciptaan alam semesta, bahkan Allāh Swt mengajak manusia memikirkan
kekuasaan-Nya yang ada pada diri manusia pada surah Ar-Rūm ayat 8, adapun Ar-Rūm ayat 21 mengajak manusia memikirkan karunia Allāh Swt pada dirinya dan pasangannya (Shihab, 2009, hlm. 162),

\section{c. Termotivasi Melakukan Kebaikan;}

Terdapat ayat-ayat yang mengajak manusia berpikir mengenai kekuasaan Allāh beserta ciptaan-Nya dan syariat Islām agar manusia memahami hikmah di dalamnya dan termotivasi melakukan kebaikan. Misalkan larangan beramal dengan niat selain Allāh dalam Al-Baqarah ayat 266 bertujuan agar manusia memurnikan amalnya bukan karena dorongan duniawi. Ayat tersebut bermakna agar manusia berpikir kemudian termotivasi untuk beramal dengan sebaikbaiknya (Thabathaba'i, 2011, hlm. 333). Adapula larangan tentang khamr dalam Al-Baqarah ayat 219 bertujuan untuk menjaga akal manusia sehingga bisa membedakan kebaikan (Thabathaba'i, 2011, hlm. 351).

Begitupun jika kita lihat ayat-ayat tentang berpikir yang menerangkan alam semesta, dengan memikirkan alam semesta yang merupakan tanda-tanda kekuasaan Allāh, maka manusia akan semakin termotivasi untuk melakukan kebaikan. Ia akan memiliki keyakinan bahwa setiap perbuatannya akan dibalas oleh Allāh Swt. Setiap amalan yang tidak ikhlas karena Allāh pada dasarnya adalah batil, ia tidak akan memperoleh balasan dari Allāh, hanya balasan di dunia dari apa yang dia inginkan.

\section{d. Diangkat Derajatnya}

Terdapat satu ayat tentang berpikir yang menyatakan bahwa Allāh akan mengangkat derajat orang-orang yang mau berpikir dengan baik yaitu surah Al-Arāf ayat 176. Dalam ayat tersebut Allāh merendahkan orang-yang tidak mau berpikir dan malah mengikuti hawa nafsunya seperti anjing yang selalu menjulurkan lidahnya karena nafsunya 
tidak juga terpenuhi. Orang yang selalu berpikir akan ditinggikan derajatnya baik di sisi Allāh maupun di sisi manusia karena ia mempunyai ilmu pengetahuan sebagaimana Allāh mengangkat orangorang berilmu (lihat Al-Mujadilah ayat 11).

\section{e. Terhindar dari Hawa Nafsu \\ Ayat-ayat yang memerintahkan} manusia berpikir mengenai bahaya menuruti hawa nafsu agar ia terhindar darinya. Misalnya Allāh Swt mengecam orang yang selalu memperturut hawa nafsunya dan cenderung pada duniawi dalam surah Al-Arāf ayat 176 (Al-Jazairi, 2010, hlm. 201). Padahal dalam surah Yūnus ayat 24, Allāh Swt menjelaskan bagaimana rapuhnya dunia yang sering dijadikan sandaran dan kebanggaan manusia (Quthb, 2004, hlm. 110). Dengan berpikir, maka manusia dapat menggunakan akalnya untuk memilih hal yang baik dan benar. Ia akan menyadari kekuasaan Allāh Swt dan mencurahkan ketaatan dan harapan pada-Nya sebagaimana dalam Āl-Imrān ayat 191 menjelaskan bagaimana orang yang telah menundukan hawa nafsunya dan selalu mengerahkan pikirannya terhadap kekuasaan Allāh Swt. Dengan penjelasan tersebut, diharapkan manusia memahami bahayanya hawa nafsu sehingga berusaha menghindarinya (Al-Qarni, 2007, hlm. 346).

\section{f. Mendapatkan Ilmu Pengetahuan.}

Kebanyakan ayat mengenai berpikir mengajak manusia berpikir dengan memperhatikan alam semesta sebagai ciptaan Allāh. Dengan meneliti alam semesta maka akan didapat pengetahuan yang seharusnya membuat manusia semakin takjub dan menyadari akan adanya Allāh sebagai pencipta dan pengaturnya. Berpikir akan mendekatkan manusia pada kebenaran dan mendapatkan ilmu pengetahuan yang tidak hanya mempermudah kehidupan, namun juga membentuk akhlak mulia. Contoh kecilnya dalam surah An-Naḥl ayat 11 yang membicarakan turunnya air hujan hingga menumbuhkan tanaman-tanaman dan buah-buahan (Ash-Shiddieqy, 2000, hlm. 2211). Dengan meneliti ayat ini, maka kita akan mendapatkan pengetahuan tentang air (Hidrologi), Biologi, Geografi, dan lainnya. Kemudian surah An-Naḥl ayat 69 mengajak manusia memikirkan seekor lebah yang menghasilkan madu (AlJazairi, 2010, hlm. 233). Jika diteliti lebih dalam, maka menurut peneliti kita akan menemukan apa manfaatnya, proses terbentuknya, sifat lebah madu yang bisa diteladani, hingga lebah madu yang menghasilkan sesuatu yang penuh manfaat.

\section{Kedudukan Berpikir (Al-Fikr) dalam Alquran}

Dari analisis terhadap ayat-ayat yang terdapat term Al-Fikr (الفكر ) peneliti menemukan kedudukan berpikir dalam Alquran sebagai berikut:

a. Berpikir Sangat Dimuliakan Allāh

Perintah untuk berpikir begitu jelas

di dalam Alquran, bahkan Alquran mengecam orang-orang yang tidak mau berpikir sehingga tidak bisa mengambil pelajaran atau hikmah. Dalam surah AlArāf ayat 176 Allāh akan meninggikan derajat orang-orang yang mau menggunakan pikirannya dan menghinakan orang yang tidak mau berpikir (Al-Jazairi, 2010, hlm. 200). Adapun dalam surah Al-An'ām ayat 50 Alquran membedakan orang yang berpikir sebagai orang yang bisa melihat dibandingkan dengan orang yang tidak berpikir seperti orang buta. Maka dari itu tentunya berpikir dalam Alquran sangat dimuliakan.

b. Mendapat Rahmat dan Terhindar dari Azab;

Dari analisis terhadap surah Āl-Imrān ayat 191 peneliti menemukan bahwa dalam surah ini menggambarkan bagaimana orang yang berpikir selalu 
berdoa dengan penuh harapan agar mendapatkan rahmat dan terhindar dari azab Allāh Swt (Al-Qarni, 2007, hlm. 346). Adapun dalam surah Saba' ayat 46 memerintahkan manusia untuk berpikir mengenai Nabi Muhammad dan ajaran yang dibawanya. Ia merupakan peringatan bagi manusia agar mereka memikirkan kandungannya sehingga mendapatkan rahmat Allāh dan terhindar dari azab yang keras (Ath-Thabari, 2009, hlm. 444).

\section{Cara Berpikir (Al-Fikr) Menurut Alquran}

Dari analisis terhadap ayat-ayat yang terdapat term Al-Fikr (الفكر) peneliti menemukan cara berpikir menurut Alquran sebagai berikut:

\section{a. Berpikir dengan Hati yang Bersih;}

Alquran memerintahkan manusia untuk berpikir bukan hanya dengan akalnya yang cerdas namun juga harus diiringi oleh hati yang bersih. Tidak sedikit orang-orang yang cerdas dalam berpikir namun dicekal oleh Alquran. Misalnya surah Al-Mudaṡsiir ayat 18 menceritakan Al-Walid Al-Mugirah seorang yang pandai yang ditunjuk kaumnya. Ketika berpikir dengan jernih ia mendapatkan kebenaran, namun ketika dipengaruhi kaumnya tentang kedudukannya dan hartanya membuat Al-Walid berpaling dari kebenaran (Al-Qurthubi, 2009, hlm. 548). Begitupun surah Al-Arāf ayat 176 ayat ini mengecam orang yang memperturut nafsu dan syahwatnya padahal Allāh menjanjikan derajat yang tinggi bagi orang yang menjauhinya (Al-Jazairi, 2010, hlm. 200). Berpikir objektif tanpa mengikuti kecenderungan nafsu pribadi sangat dibutuhkan untuk mendapatkan kebenaran. Orang yang berpikir dilandaskan dorongan kepentingan tertentu akan sulit menerima kebenaran.

b. Berpikir dengan Rasio/Logika Akal yang Benar disertai Bimbingan Wahyu;
Dalam Alquran berpikir dengan akal logika saja tidaklah cukup, melainkan harus disertai bimbingan wahyu. Akal memiliki keterbatasan sehingga membutuhkan tuntunan langsung dari Allāh berupa wahyu yang disampaikan pada seorang Rasul-Nya. Dalam surah AlArāf ayat 184 Al-Qur'ān mengajak berpikir dengan benar melakukan pengecekan dan penelaahan kembali dengan akal yang baik mengenai Nabī Muhammad Saw. Berbagai tuduhan yang dilontarkan padanya sama sekali tidak benar karena berdasarkan nafsu dan bukan akal sehat yang benar (Hamka, 1983, hlm. 183). Kemudian dalam surah Al-An'ām ayat 50 peneliti menemukan bahwa apa yang diajarkan Rasulullah saw tersebut didasarkan pada wahyu. Al-Qur'ān membedakan orang yang mampu menangkap kebenaran wahyu dengan yang tidak (Quthb, 2004, hlm. 94).

c. Berpikir Luas dengan Cara yang Sederhana agar Mudah Dipahami;

Tidak sedikit ayat-ayat Alquran mengenai berpikir menggunakan pendekatan perumpamaan (amtsal) agar lebih sederhana dan mudah dipahami. Misalnya dalam surah Yūnus ayat 24 memperumpamakan kehidupan dunia yang indah ini ibarat kebun yang indah namun tiba-tiba menghilang seolah-olah tidak pernah ada. Begitulah hakikat dunia ini tidak akan abadi maka tidak selayaknya dijadikan tujuan hidup (Quthb, 2004, hlm. 110). Al-Baqarah ayat 266 juga memperumpamakan kesia-siaan amalan berdasarkan ria, ibarat orang yang ketika mudanya bekerja keras membuat kebun yang indah, namun ketika berumur tua kebun itu lenyap dan tak mungkin ia bekerja lagi untuk membuat kebun itu karena masa mudanya telah habis (Thabathaba'i, 2011, hlm. 332).

\section{d. Terbuka dengan Pemikiran Orang Lain \\ Alquran memerintahkan manusia untuk berpikir dengan baik dan memiliki}


sifat keterbukaan untuk mendapatkan kebenaran. Dalam surah Saba' ayat 46 Allāh Swt memerintahkan manusia untuk terbuka menerima pendapat orang lain dengan cara saling berdialog dan berdiskusi memikirkan bersama-sama mengenai kebenaran ajaran yang dibawa Rasul Allāh (Hamka, 1988, hlm. 190). Sifat keterbukaan menerima pendapat orang lain harus dimiliki seseorang agar ia bisa menerima kebenaran dari pendapat orang lain dan bersikap toleran.

e. Berpikir dari Proses hingga Dampak yang Dihasilkan.

Perintah berpikir dalam Alquran harus dilakukan secara komprehensif dari proses hingga dampak yang dihasilkan. Kegiatan berpikir selain harus dilakukan dengan baik dan benar juga harus membawa manfaat. Secara tersirat peneliti menemukan dalam surah An-Nahl ayat 69 memerintahkan manusia memikirkan bagaimana proses lebah mulai dari memilih bunga yang baik hingga menghasilkan sesuatu yang bermanfaat yaitu madu (Al-Jazairi, 2010, hlm. 233). Adapun surah Al-Baqarah ayat 219 mengajak manusia memikirkan dampak dari khamr lebih banyak kerugiannya dibandingkan manfaatnya (Thabathaba'i, 2011, hlm. 351). Dengan demikian diharapkan manusia yang telah berpikir dapat menjauhi khamr tersebut.

\section{Implikasi Berpikir (Al-Fikr) Menurut Alquran Terhadap Pembelajaran PAI Di Sekolah}

\section{a. Implikasi Filosofis}

Secara folosofis, surah Āl-Imrān ayat 191 menjelaskan bagaimana orangorang yang telah berpikir dengan baik sehingga ia dekat dengan Tuhannya. Berbagai kejadian di bumi seperti pergantian siang-malam, pergantian cuaca, turunnya hujan, perbedaan musim dan lainnya adalah tanda-tanda bagi orang yang berpikir bahwa semua itu tidak terjadi dengan sendirinya (Hamka, 1993, hlm. 196). Mereka memandang bahwa ayat kauniyah dengan segala sifatnya merupakan bukti kekuasaan Allāh Swt. Maka bersemilah rasa takut dan khawatir sehingga mereka berdoa seperti dalam ayat tersebut (Al-Qarni, 2007, hlm. 346).

Hal itu lah yang harus menjadi tujuan dari pembelajaran PAI, yaitu menjadikan para siswa menjadi manusia-manusia yang bisa berpikir dengan baik sehingga menemukan dan semakin dekat dengan Allāh Swt. Dengan demikian ia akan selalu berdoa, berharap, dan taat terhadap Allāh Swt. Kedekatannya dengan Allāh Swt akan membuatnya memiliki karakter yang baik sebagaimana yang telah diajarkan oleh Allāh Swt melalui rasul-Nya. Dengan demikian ia akan tahu dan menjalankan perannya menjadi manusia sebagai khalifah dan tugasnya untuk menjaga dan merawat bumi sebagai wakil khalifah Allāh Swt. Dengan demikian akan tercipta individu yang baik dan masyarakat yang baik sehingga menjadi rahmatan lil alamin.

b. Implikasi Paedagogis Teoritis

a) Implikasi Terhadap Tujuan PAI

Tujuan dari pembelajaran PAI selaras dengan ayat-ayat Alquran yang mengandung term berpikir (Al-Fikr). Tujuan Alquran memerintahkan manusia untuk berpikir adalah agar manusia semakin mengenal Allāh sebagai pencipta dan pengatur alam semesta. Dengan demikian akan berimplikasi terhadap penyembahan hanya pada Allāh dan mentaati perintah-Nya untuk berakhlak baik.

Dalam analisa peneliti pada surah AlJāsiyah ayat 13 , An-Naḥl ayat 11, An-Naḥl ayat 69, Ar-Rūm ayat 8, Ar-Rūm ayat 21, Ar-Ra'd ayat 3, dan Āl-Imrān ayat 190, Allāh memerintahkan manusia untuk memperhatikan dan memikirkan alam semesta hingga manusia mengetahui kekuasaan Allāh yang telah menciptakan dan mengaturnya. Setelah banyak berpikir dan merenungkan ciptaan Allāh Swt maka ia akan menyadari kekuasaan Allāh Swt 
serta selalu mengharap ridha, pertolongan dan hanya menyembah pada-Nya sebagaimana yang difirmankan dalam surah Āl-Imrān ayat 191.

\section{b) Implikasi Terhadap Perencanaan PAI}

Terdapat ayat-ayat yang bisa diimplementasikan terhadap perencanaan pembelajaran PAI terutama dalam langkah pembelajaran. Dalam perspektif Alquran ilmu hanya bisa didapatkan jika kita berpikir dengan baik tanpa hati yang kotor oleh nafsu dan dosa. Dalam surah AlMudaṡsir ayat 18 Allāh mengecam cara berpikir Al-Walid (Hamka, 1985, hlm. 212). Begitupun surah Al-Arāf ayat 176 Alquran mengecam cara berpikir orang yang berdasarkan nafsu (Al-Jazairi, 2010, hlm. 200). Maka dari itu sebelum pemebelajaran dimulai, hendaklah guru PAI menyusun pembelajaran dengan terlebih dahulu mengajak siswa untuk membersihkan dosa dengan cara bertaubat memohon ampun pada Allāh.

Selain memulai pembelajaran dengan doa, menurut peneliti alangkah baiknya jika guru memulainya pula dengan ajakan untuk merenungi kekuasaan Allāh Swt dan mensyukurinya sebagaimana perintah-Nya dalam surah Al-Jāsiyah ayat 13, An-Naḥl ayat 11 , An-Naḥl ayat 69 , Ar-Rūm ayat 8 , Ar-Rūm ayat 21, Ar-Ra'd ayat 3, dan ĀlImrān ayat 191. Ajak dan ingatkanlah siswa untuk memperhatikan berbagai kejadian alam maupun sosial di sekitarnya. Berikan rangsangan pada siswa agar mereka berpikir dan merenungi nikmat dan manfaat di dalamnya. Arahkan perhatian siswa pada nikmat Allāh Swt di sekitarnya, walaupun itu tampak kecil dan sederhana, namun guru menjelaskannya dengan katakata indah lagi penuh hikmah yang membuat kagum sehingga memunculkan rasa syukur.

c) Implikasi Terhadap Guru PAI
Seorang guru terutama guru PAI hendaklah meniru bagaimana Rasulullah Saw dalam mendidik. Menurut Hamka (1983, hlm. 183) surah Al-Arāf ayat 184 Alquran menegaskan bahwa Nabī Muhammad saw bukanlah seperti dugaan buruk kaum Quraisy, Alquran menyuruh mereka berpikir kembali mengenai kepribadian Nabī Muhammad saw. Bahkan menurut Shihab (2008, hlm. 327 dalam ayat ini Nabī Muhammad saw dinamai teman mereka. Karena mereka selalu bersama beliau semenjak masa sebelum kenabian. Teman yang selalu menyertai seseorang adalah yang paling mengenalnya. Tentu mereka sangat mengenal Nabī Muhammad. Sebelum menjadi nabi, beliau terkenal oleh penduduk Mekkah sebagai orang yang berkepribadian baik bahkan mendapat gelar al-amin (terpercaya), padahal saat itu masih dalam keadaan jahiliyah. Seorang guru hendaklah memiliki kepribadian yang baik sebagaimana Nabī Muhammad saw.

d) Implikasi Terhadap Materi Pembelajaran PAI

Dalam temuan peneliti, materi pembelajaran yang diajarkan oleh $\mathrm{Nabī}$ Muḥammad saw berasal dari wahyu Allāh, sebagaimana yang difirmankan surah AlAn'ām ayat 50 tugas rasul hanyalah menerima ajaran dari Rabb-nya dan hanya mengikuti apa yang diwahyukan (Quthb, 2004, hlm. 94). Hendaklah dalam pembelajaran PAI tidak hanya berisi materi agama seperti fiqih, aqidah, sejarah Islām dan lainnya. Hendaklah juga ditambahkan atau dikaitkan dengan materi ilmu umum seperti ilmu alam atau humaniora. Sebab Alquran pun memerintahkan demikian dalam surah AlJāsiyah ayat 13, An-Naḥl ayat 11, An-Naḥl ayat 69 , Ar-Rūm ayat 8 , Ar-Rūm ayat 21 , Ar-Ra'd ayat 3, dan Āl-Imrān ayat 191 yang memerintahkan untuk meneliti alam semesta dan isinya.

e) Implikasi Terhadap Metode Pembelajaran PAI 
Dalam surah Yūnus ayat 24 Allāh menggunakan metode amtsal atau perumpamaan dalam menerangkan dunia yang fana dan sementara (Quthb, 2004, hlm. 110). Dalam surah. Al-Baqarah ayat 266 Allāh memperumpamakan kemalangan orang yang beramal berdasarkan ria di akhirat kelak karena pahala yang selama ini diharapkan hilang tak kembali lagi (Al-Qarni, 2007, hlm. 213). Alquran juga menggunakan metode pembelajaran dialog atau Hiwar Qurani, dalam surah Saba' ayat 46 menurut Hamka (1988, hlm. 190) Allāh memerintahkan orang-orang yang membantah Rasulullah Saw untuk berpikir saling bertukar pemikiran dengan cara berdialog dan berdiskusi untuk memikirkan kembali tentang Nabī Muhammad saw secara benar. Pikirkan segala kata dan seruan, ajakan dan dakwah yang disampaikan Nabī Muhammad saw. Jika pikiranmu jernih maka akan disimpulkan bahwa Rasūl Allāh saw tidaklah gila. Metode kisah qur'ani juga digunakan agar siswa berpikir untuk mengambil pelajaran atau hikmah dari kisah-kisah terdahulu. Dalam kisah-kisah tersebut terdapat banyak pelajaran yang bisa diterapkan di zaman sekarang. Surah Al-Arāf ayat 176 memerintahkan agar menceritakan bagaimana kisah orang-orang terdahulu yang selalu mengikuti hawa nafsunya dan durhaka pada Allāh Swt. Dengan dicaritakannya kisah tersebut, maka hendaklah manusia berpikir dan merenunginya sehingga mendapatkan hikmah dan pelajaran di dalamnya (AlMaragi, 1992, hlm. 2013).

\section{f) Implikasi Terhadap Media Pembelajaran PAI}

Media pembelajaran juga terdapat dalam ayat-ayat Alquran yang mengandung term Al-Fikr. Kebanyakan Alquran memakai media langsung untuk mengajak memperhatikan alam semesta sebagai objek untuk berpikir, kemudian menelaahnya sehingga munculah keimanan yang kuat. dalam surah Al-
Jāsiyah ayat 13, An-Naḥl ayat 11, An-Naḥl ayat 69 , Ar-Rūm ayat 8, Ar-Rūm ayat 21, Ar-Ra'd ayat 3, dan Āl-Imrān ayat 191 memerintahkan manusia untuk langsung meneliti alam sebagai media pembelajaran mengenal Allāh. Dengan demikian hendaklah dalam pembelajaran PAI juga menggunakan media langsung dari alam, misalnya mengadakan percobaan saintifik kemudian dikaitkan dengan materi pembelajaran PAI.

Implikasi terhadap Evaluasi
Pembelajaran PAI
Dalam surah Āl-Imrān ayat 191 terdapat unsur evaluasi dari hasil proses berpikir sebagaimana yang diperintahkan dalam Alquran. orang yang selalu berpikir dengan akal dan hatinya yang bersih maka akan menemukan kebenaran dan semakin dekat dengan Tuhan. Ia akan berkata "Ya Tuhan Kami, Tiadalah Engkau menciptakan ini dengan sia-sia, Maha Suci Engkau, Maka peliharalah Kami dari siksa neraka" sebagai ucapan yang muncul dari perenungan, dzikir dan pemikiran mengenai ciptaan Allāh (Hamka, 1993, hlm. 198).

Implikasinya bagi evaluasi pembelajaran PAI hendaklah para guru tidak hanya mengevaluasi sejauh mana pengetahuan murid seputar agama. Namun lebih dari itu guru PAI harus melihat sejauh mana ilmu agama yang telah dipelajari dapat dipahami dan diamalkan peserta didiknya dalam kehidupan seharihari minimal di lingkungan sekolah. Selalu mengingat dan memikirkan Allāh merupakan puncak dari pemahaman dan pengamalan ilmu agama yang telah dipelajari.

c. Implikasi Praktis

Guru PAI harus menjelaskan dan merangsang siswa untuk bisa berpikir mengambil hikmah serta manfaat dari materi pembelajaran agama yang diajarkan sehingga terkesan di benak siswa. Metode pembelajaran PAI yang bisa digunakan yaitu metode dialog atau diskusi yang bisa merangsang siswa untuk berpikir 
mengemukakan argumen yang baik, metode amtsal perumpamaan yang membuat siswa lebih mudah memahami materi, dan metode kisah yang membuat siswa lebih peka menangkap hikmah dari setiap kisah dan peristiwa yang terjadi.

Adapun media pembelajaran yang bisa digunakan adalah media dari berbagai peristiwa dan kejadian-kejadian alam semesta baik secara langsung maupun tidak langsung melalui gambar atau video. Guru PAI tidak hanya menerangkan materi agama saja, namun juga harus mengaitkan ayat-ayat kauniyah Allāh Swt yang ada di alam semesta dan mengaitkannya pada pembelajaran agama. Guru PAI menghadirkan media pembelajaran tersebut dengan menyuruh siswa mengamatinya, kemudian merangsang siswa agar mampu menangkap hikmah dan filosofi dari berbagai kejadian itu dikaitkan dengan pembelajaran agama.

Setiap pembelajaran PAI di sekolah bertujuan agar siswa mengetahui, memahami, menghayati, hingga mengamalkan materi yang telah dipelajari. Semua itu dilakukan melalui proses bukan secara instan atau langsung. Guru harus terus bersabar dan membimbing siswa. Guru harus mempunyai pandangan untuk menjadikan siswa-siswanya tidak hanya mengetahui ajaran Islām, namun juga bisa mengamalkannya.

\section{KESIMPULAN}

Pengembangan potensi berpikir menurut Islām yaitu agar pengembangan pembelajaran harus senantiasa bersifat integratif. Kajian ayat-ayat Allāh dan kajian ayat-ayat kauniyah tidak terpisahkan dari nilai inti pendidikan Islām yakni keterarahan penuh pada Sang Pencipta. Allāh Swt melalui Alquran memerintahkan hamba-Nya untuk selalu berpikir dengan baik sehingga mendapatkan ilmu pengetahuan agar dapat mengenal Allāh Swt.

Syariat Islām hanya bisa dilaksanakan oleh orang-orang yang mempunyai akal dan mampu berpikir.
Adapun orang yang mempunyai akal namun tidak digunakan untuk berpikir dengan baik maka tidak bisa menerapkan syariat Islām dalam dirinya, bahkan ia akan berbalik menolaknya. Dalam Alquran terdapat 18 surah dengan term 'berpikir' (al-fikr) yang baik secara langsung ataupun tidak menyuruh manusia berpikir.

Objek berpikir dalam Alquran bukanlah memikirkan zat Allāh Swt, namun memikirkan hikmah dari ciptaan Allāh Swt di alam semesta, kekuasaan Allāh Swt dalam mengatur alam semesta, dan nikmat Allāh Swt yang terdapat di alam semesta. Alquran mengajak manusia untuk memikirkan alam semesta, diri manusia, dan hikmah dari syariat atau segala perintah dan larangan Allāh Swt. Dengan cara demikian, manusia bisa semakin dekat dan kenal dengan Allāh Swt sehingga akan menghasilkan akhlak yang baik sebagai perwujudannya terhadap kedekatan dan ketaatan pada Allāh Swt.

\section{REFERENSI}

Al-Jazairi, A. B. (2010a). Tafsir Al-Quran Al-Aisar (Jilid 3). (Suratman, Penerj.) Jakarta: Darus Sunnah Press.

Al-Jazairi, S. A. (2010b). Tafsir Al-Quran Al-Aisar (Jilid 4). (Suratman, Penerj.) Jakarta: Darus Sunnah Press.

Al-Jazairi, S. A. (2010c). Tafsir Alquran Al-Aisar (Jilid 4). (Suratman, Penerj.) Jakarta: Darus Sunnah Press.

Al-Maragi, A. M. (1992a). Tafsir AlMaragi (Juz 7, 8, Dan 9). (A. U. Sitanggal, Penerj.) Semarang: Karya Toha Putra.

Al-Maragi, A. M. (1994b). Tafsir AlMaragi. (A. U. Sitanggal, Penerj.) Semarang: Karya Toha Putra Semarang.

Al-Qarni, '. (2007). Tafsir Muyassar (Vol 1). (T. Q. Press, Penerj.) Jakarta: Qisthi Press. 
Al-Qattan, M. K. (2012). Studi Ilmu-Ilmu Qur'an. (Mudzakir, Penerj.) Bogor: Litera Antar Nusa.

Al-Qurthubi. (2009a). Tafsir Al-Qurthubi (Vol 14). (F. A. Hamid, Penerj.) Jakarta: Pustaka Azzam.

Al-Qurthubi. (2009b). Tafsir Al-Qurthubi (Vol 18) (Vol. 29). (A. Khatib, Penerj.) Jakarta: Pustaka Azzam.

Amrullah, A. A. (1983). Tafsir Al-Azhar. Jakarta: PT Pustaka Panjimas Jakarta.

Ash-Shiddieqy, H. (2000a). Tafsir AlQuranul Majid An-Nur. Semarang: Pustaka Rizkia Putra.

Ash-Shiddieqy, M. H. (2000b). Tafsir AnNur (Vol 3). Semarang: Pustaka Rizki Putra.

Ath-Thabari, A. J. (2009a). Tafsir AthThabari (Vol 21). (B. Hidayat, Penerj.) Jakarta: Pustaka Azzam.

Ath-Thabari, A. J. (2009b). Tafsir AthThabari (Vol23). (A. Somad, Penerj.) Jakarta: Pustaka Azzam.

Ath-Thabari, A. J. (2009c). Tafsir AthThabari (Vol. 25). (A. Taslim, Penerj.) Jakarta: Pustaka Azzam. Ath-Thabari, A. J. (2009d). Tafsir AthThabari. Jakarta: Pustaka Azzam.

Ath-Thabari, A. J. (2009e). Tafsir AthThabari. (Fathurrozi, \& A. Taslim, Penerj.) Jakarta: Pustaka Azzam.

Hamka. (1982a). Tafsir Al-Azhar (Juz 2427). Jakarta: Pustaka Panjimas.

Hamka. (1985b). Tafsir Al-Azhar (Juz 28,29, Dan 30). Jakarta: Pustaka Panjimas.

Hamka. (1983c). Tafsir Al-Azhar (Juz 7, 8, Dan 9). Jakarta: Pustaka Panjimas.

Hamka. (1988d). Tafsir Al-Azhar Juz (21, 22, Dan 23). Jakarta: Abadi Grup.

Hamka. (1993e). Tafsir Al-Azhar Juz V. Jakarta: Pustaka Panjimas.

Izzan, A. (2013). Ulumul Quran. Bandung: Tafakur.

Katsir, I. (2006). Tafsir Ibn Katsir (Jilid 4). (A. Ghoffar, Penerj.) Jakarta: Pustaka Imam Syafi'i.
Langgulung, H. (2004). Manusia Dan Pendidikan. Jakarta: Pustaka AlHusna Baru.

Majid, A. (2012). Belajar Dan Pembelajaran Pendidikan Agama Islām. Bandung: Rosda.

Mas'ud, I. (2009). Tafsir Ibn Mas'ud. (A. M. Syahudi, Penerj.) Jakarta: Pustaka Azzam.

Qurthubi, S. I. (2008). Tafsir Al Qurthubi. Jakarta: Pustaka Azzam.

Quthb, S. (2004a). Tafsir Fi Dzilalil Qur'an (Jilid 11). (A. Yasin, Penerj.) Jakarta: Gema Insani.

Quthb, S. (2004b). Tafsir Fi Dzilalil Qur'an (Jilid 4). (A. Y. Dkk, Penerj.) Jakarta: Gema Insani.

Quthb, S. (2004c). Tafsir Fi Dzilalil Quran (Jilid10). (A. Yasin, Penerj.) Jakartta: Gema Insani Press.

Quthb, S. (2004d). Tafsir Fi Zhilalil Qur'an (Vol. 6). (A. Yasin, Penerj.) Jakarta: Gema Insani.

Shihab, Q. (2008b). Tafsir Al-Mishbah (Vol 5). Tanngerang: Lentera Hati.

Shihab, Q. (2009c). Tafsir Al-Mishbah (Vol10). Jakarta: Lentera Hati.

Shihab, Q. (2009d). Tafsiral-Mishbah (Vol 11). Jakarta: Lentera Hati.

Sukmadinata, N. S. (2012). Metode Penelitian Pendidikan. Bandung: Rosda.

Thabathaba'i, S. M. (2011a). Tafsir AlMizan (Vol 3). (I. Hasan, Penerj.) Jakarta: Penerbit Lentera.

Thabathaba'i, S. M. (2011b). Tafsir AlMizan (Vol 4). (I. Hasan, Penerj.) Jakarta: Penerbit Lentera.

Tim Dosen UPI. (2015). Pedoman Penulisan Karya Tulis Ilmiah UPI tahun 2015. Bandung: UPI. 